\title{
Antitumor effects of $\beta$-elemene via targeting the phosphorylation of insulin receptor
}

\author{
Dawei Wu1,*, Dongwei Lv2,*,t, Ting Zhang1,*, Lianying Guo1, Fangli Ma1, Caihua Zhang1, Guofeng Lv² and Lin Huang1 \\ 'Department of Pathophysiology, College of Basic Medical Sciences, Dalian Medical University, Dalian, Liaoning, China \\ 2Department of Sports Medicine, College of Basic Medical Sciences, Dalian Medical University, Dalian, Liaoning, China
}

Correspondence should be addressed to L Huang or G Lv: Ihuang@dmu.edu.cn or gf1113@qq.com

*(D Wu, D Lv and T Zhang contributed equally to this work)

${ }^{\dagger}(\mathrm{D}$ Lv is now at Dongying People's Hospital, Dongying, Shandong, China)

\begin{abstract}
Ewing sarcoma family tumors (ESFTs) are a group of aggressive and highly metastatic tumors lacking efficient therapies. Insulin-like growth factor 1 receptor (IGF1R) blockade is one of the most efficient targeting therapy for ESFTs. However, the appliance is obstructed by drug resistance and disease recurrence due to the activation of insulin receptor (IR) signaling induced by IGF1R blockade. Herein $\beta$-elemene, a compound derived from natural plants, exhibited a remarkable proliferation repression on ESFT cells, which was weakened by a caspase inhibitor Z-VAD. $\beta$-elemene in combination with IGF1R inhibitors enhanced markedly the repression on cellular proliferation and mTOR activation by IGF1R inhibitors and suppressed the PI3K phosphorylation induced by IGF1R inhibitors. To investigate the mechanisms, we focused on the effects of $\beta$-elemene on IR signaling pathway. $\beta$-elemene significantly suppressed the insulin-driven cell growth and the activation of mTOR and PI3K in tumor cells, while the toxicity to normal hepatocytes was much lower. Further, the phosphorylation of IR was found to be suppressed notably by $\beta$-elemene specifically in tumor cells other than normal hepatocytes. In addition, $\beta$-elemene inhibited the growth of ESFT xenografts in vivo, and the phosphorylation of IR and $\mathrm{S} 6$ ribosomal protein was significantly repressed in the $\beta$-elemene-treated xenografts. These data suggest that $\beta$-elemene targets IR phosphorylation to inhibit the proliferation of tumor cells specifically and enhance the effects of IGF1R inhibitors. Thus, this study provides evidence for novel approaches by $\beta$-elemene alone or in combination with IGF1R blockades in ESFTs and IR signaling hyperactivated tumors.
\end{abstract}

\author{
Key Words \\ - $\beta$-elemene \\ - antitumor therapy \\ - insulin receptor signaling \\ - insulin-like growth factor 1 \\ receptor blockade
}

\section{Introduction}

Ewing sarcoma family tumors (ESFTs) are a group of aggressive and highly metastatic tumors predominantly afflicting children and young adults. With conventional treatments including chemotherapy, radiotherapy and a multimodal therapy of surgical resection associated with local radiotherapy and chemotherapy, the long-term survival rate for patients with localized tumors is only
$70 \%$ and that for individuals with metastases is less than $20 \%$. Thus, novel treatments are needed urgently.

The reciprocal chromosomal translocation $t(11 ; 22)$ (q24;q12) is found in $85 \%$ of ESFTs, which leads to the fusion between the $5^{\prime}$ segment of the Ewing sarcoma breakpoint region 1 gene (EWSR1) and the 3 ' portion of Friend leukemia virus integration site 1 gene (FLI1). (c) 2019 The authors Published by Bioscientifica Ltd. Printed in Great Britain
Endocrine-Related Cancer (2019) 26, 187-199 
The resulting EWS-FLI1 fusion protein induces insulin-like growth factor 1 (IGF1) expression and suppresses the expression of insulin-like growth factor-binding protein 3 (IGFBP3) (Prieur et al. 2004, France et al. 2011), therefore enhancing the IGF1 signaling in ESFTs. Hyperactivated IGF1 signaling contributes to the ESFT tumorigenesis. High levels of circulating IGF1 are also associated with the development of several other tumors, including breast cancers, prostate cancers and sarcomas (Renehan et al. 2004). Downregulation of IGF1 receptor (IGF1R) expression or blocking IGF1R signaling leads to tumor growth suppression (Sachdev \& Yee 2007, Ryan \& Goss 2008) and increases the susceptibility of tumor cells to chemotherapies (Tao et al. 2007, Chitnis et al. 2008, Ryan \& Goss 2008). IGF1R targeting therapies exhibit remarkable activity toward ESFTs in clinical studies (Kurzrock et al. 2010, Olmos et al. 2010). However, the use of IGF1R blockade in patients is associated with hyperinsulinemia which stimulates the proliferation of epithelial cells (Gualberto \& Pollak 2009, Pollak 2012). The holo-insulin receptor (IR) formation and the signaling of IR pathway is activated by IGF1R depletion (Zhang et al. 2007), and overexpression of IR and IGF1 may result in resistance to IGF1R-targeting therapies (Zhang et al. 2007, Hendrickson $\&$ Haluska 2009). IR exists in two splice variant isoforms, IR-A and IR-B, which could be activated by insulin (Sciacca et al. 2003). In addition, IGF2 can activate IR-A other than IR-B (Sciacca et al. 2002). Meanwhile, lots of ESFT patients develop resistance to IGF1R targeting and disease recurrence within several months (Toretsky \& Gorlick 2010), and a major mechanism may involve increased IR-A expression, enhanced IR homodimer formation and an activation of IR signaling pathways (Garofalo et al. 2011, Lamhamedi-Cherradi et al. 2016). Notably, the IR-knockout tumors exhibited more sensitivity to antiIGF1R therapy (Ulanet et al. 2010). Therefore, inhibition of both IR and IGF1R signaling may enhance therapeutic efficacy against IGF1-driven cancers (Sachdev \& Yee 2007). However, the IR blockade was considered to be too dangerous due to the significant impairment on glucose metabolism.

$\beta$-elemene (1-methyl-1-vinyl-2, 4-diisopropenylcyclohexane), a compound derived from natural plants, including lemon grass and Curcuma wenyujin plant, has been clinically used to treat several kinds of tumors. $\beta$-elemene inhibits proliferation, induces apoptosis, reverses the drug resistance and enhances chemotherapeutic sensitivity of cancer cells (Li et al. 2013, 2016, Wu et al. 2017). However, the molecular mechanisms in detail remain largely unknown. In addition, the effects of $\beta$-elemene on ESFTs are to be determined. In this study, we find that $\beta$-elemene represses the proliferation of ESFT cells, enhances the anti-growth effects of IGF1R inhibitors on ESFT cells and decreases the phosphorylation of IR in tumor cells other than normal hepatocytes. Thus, this study provides the evidence for $\beta$-elemene alone or in combination with IGF1R blockades as novel treatments for ESFTs and IR signaling hyperactivated tumors.

\section{Materials and methods}

\section{Cell lines and cell culture}

The ESFT cell line A673, the heptacellular carcinoma cell line HepG2, the normal liver cell line THLE2 and the melanoma cell line A2058 were purchased from ATCC, and MHH-ES-1 was purchased from Deutsche Sammlung von Mikroorganismen und Zellkulturen (DSMZ, Germany). These cells were tested by the cell banks for eight STR loci and the amelogenin gene. A673, MHH-ES-1 and A2058 were grown in DMEM supplemented with $10 \%$ fetal bovine serum (FBS). HepG2 was grown in MEM supplemented with 10\% FBS. THLE2 was grown in Bronchial Epithelial Cell Growth Medium (BEGM) supplemented with $5 \mathrm{ng} / \mathrm{mL}$ EGF, $70 \mathrm{ng} / \mathrm{mL}$ phosphoethanolamine and 10\% FBS. The flasks used for THLE2 were precoated with a mixture of $0.01 \mathrm{mg} / \mathrm{mL}$ fibronectin, $0.03 \mathrm{mg} / \mathrm{mL}$ bovine collagen type I and $0.01 \mathrm{mg} / \mathrm{mL}$ bovine serum albumin dissolved in BEBM medium. All the cell lines were incubated at $37^{\circ} \mathrm{C}$ with $5 \% \mathrm{CO}_{2}$. Cell lines purchased were passaged less than 30 passages after resuscitation.

\section{Chemicals}

$\beta$-elemene (95\%) was obtained from Yuanda Pharmaceuticals (Dalian, China). Insulin was from Prospec (Israel). Picropodophyllin (PPP) was purchased from Sellek. NVP-AEW541 and Z-VAD were purchased from MedChem Express (Monmouth Junction, NJ, USA).

\section{Plasmid}

The human WT INSR (HIR WT) expression plasmid which includes the full sequence of INSR gene and encodes IR-B was a gift from Dr Frederick Stanley (Addgene plasmid \# 24049) (Jacob et al. 2002).

\section{Cell viability assay}

Cells were seeded at $5 \times 10^{3}$ cells /well into 96-well plates in triplicate. After $24 \mathrm{~h}, \beta$-elemene was added at

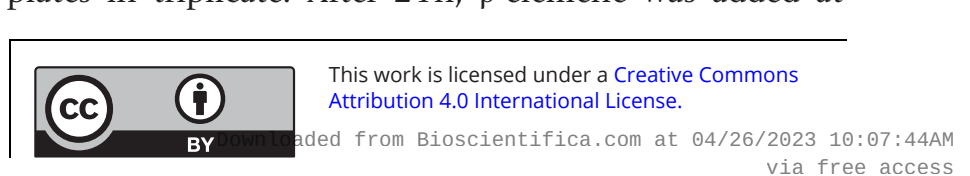


the concentration indicated. Forty eight hours later, cell proliferation was determined using Cell Counting Kit-8 (mixture of WST-8 and 1-Methoxy PMS) (Dojindo, Kumamoto, Japan) according to the manufacturer's instructions. Absorbance was measured at $450 \mathrm{~nm}$ with the reference at $630 \mathrm{~nm}$. Cell viability was calculated using the formula:

$$
\text { cell viability }(\%)=\frac{(\text { ODsample }- \text { ODblank })}{(\text { ODcontrol }- \text { ODblank })} \times 100
$$

\section{Colony formation assay}

Cells were seeded at $1.2 \times 10^{3} /$ well into 6-well plates and were exposed to various concentrations of $\beta$-elemene. After $24 \mathrm{~h}$, cells were washed with PBS and supplemented fresh medium. Two weeks later, the colonies were stained with $0.1 \%$ crystal violet. The colonies with diameter $>2 \mathrm{~mm}$ were counted.

\section{Apoptosis assay}

Apoptosis was measured by fluorescence-activated cell sorter using the Annexin V- FITC Apoptosis Detection Kit (Thermo Fisher). In brief, cells plated in six-well plates were treated with $\beta$-elemene. After treatment of $24 \mathrm{~h}$, cells were collected and washed once with cold PBS, and subsequently stained simultaneously with FITC-labeled annexin V and PI. Stained cells were analyzed using Accuri C6 (BD).

\section{Antibodies and Western blot analysis}

Antibodies were purchased for the detection of $\beta$-actin (AC-15; Sigma); PRAS40 (Invitrogen); cleaved PARP, p-Akt (S473), p-PDK1, p-PRAS40 (T246), p-PI3K (p85), p-S6 ribosomal protein, p-mTOR (S2448), S6 ribosomal protein, p-IGF1R (Y1135/1136)/p-IR (Y1150/1151), S6, Akt, PI3K (p85), mTOR, IGF1R and IR (Cell Signaling); p-IR (Y1361, Abcam); p-ERK1/2 and ERK1/2 (Abbkine). Western blot analysis was performed as described previously (Huang et al. 2014), and the signals were detected using an ECL Plus Detection System (Thermo Fisher). Images were acquired using an Image Analyzer ChemiDoc XRS+ (BioRad) and quantified with Image J software.

\section{In vivo tumorigenicity assay}

All animal maintenance and procedures were carried out in strict accordance with the recommendations established by the Animal Care and Ethics Committee of
Dalian Medical University. The protocol was approved by the Animal Care and Ethics Committee of Dalian Medical University. In animal study, all efforts were made to minimize suffering of mice.

All animals were maintained and animal experiments were conducted in the specific-pathogen-free Laboratory Animal Center of Dalian Medical University. A673 cells $\left(5 \times 10^{6}\right)$ were injected subcutaneously into the two posterior flanks of male BALB/c nude mice (Dalian Medical University). Tumors were allowed to grow for 1 week when the initial measurement was made with calipers. The mice without tumor formation or with a tumor volume 50\% bigger than the average were removed from the experiments. The mice were randomly divided into control, low $(50 \mathrm{mg} / \mathrm{kg})$ and high doses $(100 \mathrm{mg} / \mathrm{kg})$ group, and $\beta$-elemene was injected to peritumoral region once per day for up to 17 days ( $n=12$ /group). Tumors were measured with a caliper every 2 days, and the tumor volume was calculated using the formula $V=1 / 2$ (width ${ }^{2} \times$ length). Body weights were also recorded. All mice were killed on day 18 , and the tumors were dissected, weighed and measured.

\section{Immunohistochemistry}

Formalin-fixed, paraffin-embedded xenograft tumor sections were deparaffinized, dehydrated and treated with $0.3 \%$ hydrogen peroxide. Slides were incubated with anti-p-IR (Abcam) or anti-p-S6 ribosomal protein (Cell Signaling) antibodies overnight at $4^{\circ} \mathrm{C}$ followed by incubation with biotinylated secondary antibodies (Vector Laboratories, Burlingame, CA, USA) for $1 \mathrm{~h}$ at room temperature. Signals were detected using a diaminobenzidine substrate kit (Vector Laboratories). Slides were counterstained with hematoxylin.

The degree of staining was interpreted semiquantitatively by assessing the intensity and extent of staining for each slide. The percent area of positively staining analyzed with ImageJ software was multiplied by their degree of staining (none (0), weakly (1), moderate (2), strong (3)). A staining score (H-score) was then calculated (out of a maximum of 300) (Bollag et al. 2010).

\section{Statistical analyses}

All experiments were repeated thrice. The data are represented as the mean \pm standard deviation (s.D.). Differences between groups were assessed by one-way ANOVA or Student's t-test. $P<0.05$ was considered statistically significant. SPSS 17.0 software was used for all statistical analyses.

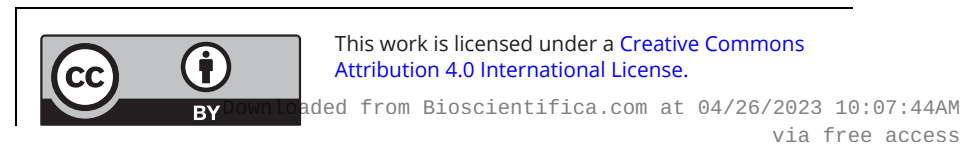




\section{Results}

\section{$\beta$-elemene represses the proliferation of ESFT cells}

To investigate the effects of $\beta$-elemene on the proliferation of ESFT cells, we treated A673 cells with increasing concentrations of $\beta$-elemene and evaluated the cellular proliferation with a cell viability assay. The cells showed a significant decline in viability compared with the control in a $\beta$-elemene-dose-dependent manner $(P<0.01)$, IC50 is $38.02 \mu \mathrm{g} / \mathrm{mL}$ (Fig. 1A). MHH-ES-1 cells, another ESFT cell line, exhibited a similar reduction as A673 cells in cell viability under $\beta$-elemene treatment compared with control $(P<0.01)$, IC50 is $47.86 \mu \mathrm{g} / \mathrm{mL}$ (Fig. 1B). Consistent with the cellular proliferation inhibition, $\beta$-elemene also significantly repressed the colony formation in both A673 and MHH-ES-1 cells in a dose-dependent manner (Fig. 1C and D).

To clarify whether the cell growth repression by $\beta$-elemene is due to inducing apoptosis, we selected a caspase inhibitor Z-VAD, which inhibits cell apoptosis to treat A673 cells together with $\beta$-elemene. The results showed that Z-VAD treatment restored the decreased cell viability by $\beta$-elemene $(40 \mu \mathrm{g} / \mathrm{mL})$ from 50 to $70 \%$ $(P<0.01)$, which suggests that $\beta$-elemene treatment may induce the apoptosis of ESFT cells (Fig. 1E).

IGF1 plays an important role in the proliferation of ESFT cells, and IGF1 was found to be able to increase
A

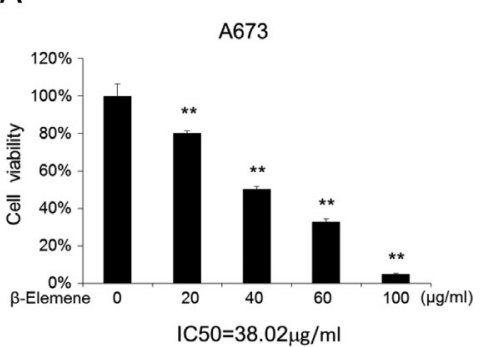

C

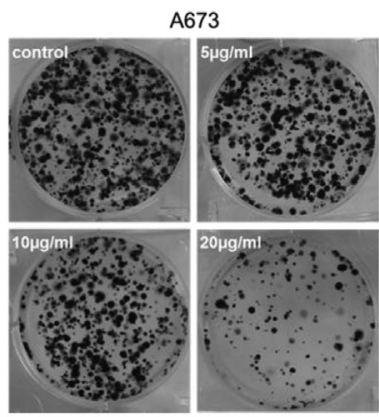

E

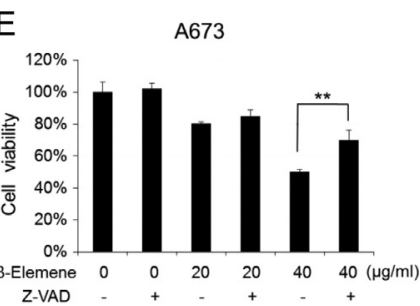

G

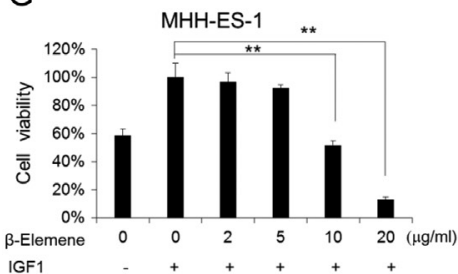

\section{B}

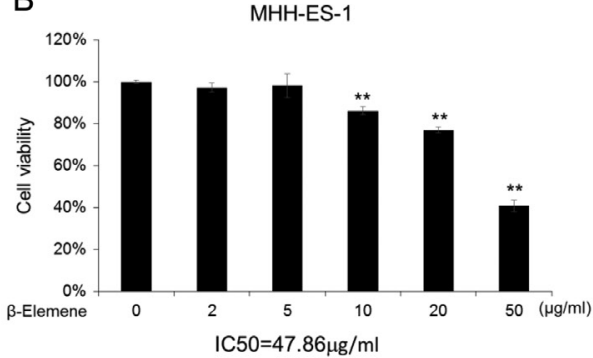

D

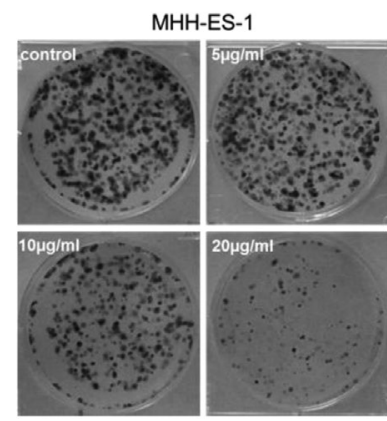

$\mathrm{F}$
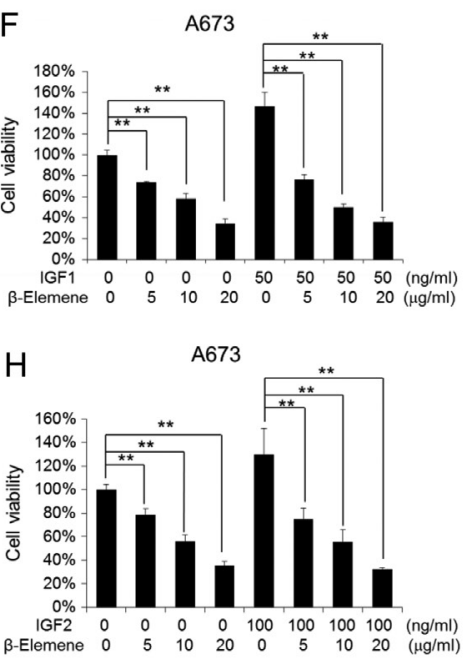

Figure 1

Effects of $\beta$-elemene on cellular proliferation. (A and B) Cell viability assays for A673 (A) MHH-ES-1 (B) cells. (C and D) Colony formation assays for A673 (C) and MHH-ES-1 (D) cells. (E) Cell viability assays for $A 673$ cells with increasing concentrations of $\beta$-elemene and Z-VAD treatment. Z-VAD, $50 \mu M$. ( $F, G$ and $H)$ Cell viability assays for A673 ( $\mathrm{F}$ and $\mathrm{H}$ ) and $\mathrm{MHH}$-ES-1 (G) cells in response to IGF1 ( $F$ and G) or IGF2 (H) stimulation. The cells were treated with or without (-) IGF1 $(50 \mathrm{ng} / \mathrm{mL})$ or IGF2 $(100 \mathrm{ng} / \mathrm{mL})$ and increasing concentrations of $\beta$-elemene after $24-h$ starvation. All the experiments were conducted in triplicate, and three independent experiments were performed. ** $P<0.01$ indicates the significant difference from the untreated cells (A and $B)$, or the particular treated cells as labeled (E, F, G and H). Bars, S.D. 
the cell growth to 1.5- to 1.7-folds compared with control. To test the anti-proliferative activity of $\beta$-elemene in the ESFT cells that were stimulated with exogenous IGF1, both A673 and MHH-ES-1 cells were treated with IGF1 and increasing concentrations of $\beta$-elemene. $\beta$-elemene $(5-10 \mu \mathrm{g} / \mathrm{mL})$ downregulated the exogenous IGF1-driven cell growth to the level of that without IGF1 treatment (Fig. 1F and G). The data showed that $\beta$-elemene remarkably inhibited the IGF1-driven ESFT cell growth dose dependently $(P<0.01)$. IGF2 production was previously reported to be increased in IGF1 blockaderesistant cell lines (Garofalo et al. 2011). Significant repressive effects on IGF2-driven cell growth as same as IGF1-driven cell growth by $\beta$-elemene treatment was confirmed (Fig. $1 \mathrm{H})(P<0.01)$. The data suggest that either IGF1- or IGF2-driven ESFT cell growth is sensitive to $\beta$-elemene treatment.

\section{$\beta$-elemene enhances the toxicity of IGF1R inhibitors on ESFT cells}

IGF1R inhibitor picropodophyllin (PPP) efficiently blocks IGF1R activity without affecting IR activity (Girnita et al. 2004). Another IGF1R inhibitor NVP-AEW541 is 27 -fold more potent to IGF1R than IR at cellular level (GarciaEcheverria et al. 2004). In A673 cells, PPP treatment showed a reduction of cell viability in a dose-dependent manner. The treatment with $\beta$-elemene alone $(30 \mu \mathrm{g} / \mathrm{mL})$ led to a $23-26 \%$ decrease in cell viability compared to the control (Fig. 2A and B). The combination treatment of $\beta$-elemene and increasing concentrations of PPP resulted in a significant reduction in cell viability compared with PPP-alone treatment $(P<0.01)$. We also treated A673 cells with $\beta$-elemene and NVP-AEW541 and obtained similar inhibitory effects on cell viability $(P<0.01)$. In MHH-ES-1 cells, PPP $(0.1 \mu \mathrm{M})$ or NVP-AEW541 $(0.2 \mu \mathrm{M})$ did not show remarkable effects on cell viability, while the combination treatment of $\beta$-elemene and PPP or NVP-AEW541 led to a notable decrease in cell viability $(P<0.01)$ (Fig. 2C and D).

Consistent with the previous reports (Zhang et al. 2007), PPP stimulated the phosphorylation of PI3K and Akt in A673 cells (Fig. 2E and F). Combination treatment of $\beta$-elemene with PPP resulted in a greater decline of PI3K and Akt phosphorylation. In addition, compared with PPP alone, combination treatment of $\beta$-elemene with PPP resulted in a greater decline in the phosphorylation of mTOR and $\mathrm{S} 6$ ribosomal protein representing the activity of mTOR.

\section{$\beta$-elemene represses the insulin-driven cellular proliferation of ESFT cells and other tumor cells}

Since IGF1R blockade treatment results in the activation of IR signaling pathway (Zhang et al. 2007, Garofalo et al. 2011, Lamhamedi-Cherradi et al. 2016) (Fig. 2E), and $\beta$-elemene enhanced IGF1R inhibitor's repression on cell viability (Fig. 2A, B, C and D), we hypothesize that $\beta$-elemene may inhibit the activation of IR signaling pathway induced by IGF1R blockade. To clarify this issue, we next investigated the effects of $\beta$-elemene on the insulin-driven cellular proliferation of ESFT cells. After the starvation, insulin $(20 \mathrm{nM}$ or $100 \mathrm{nM})$ stimulated the cell growth to 1.4-fold or 1.5-fold compared with control in A673 or MHH-ES-1 cells. Simultaneously these cells were treated with increasing concentrations of $\beta$-elemene. $\beta$-elemene remarkably inhibited the exogenous insulindriven ESFT cell growth dose dependently $(\mathrm{P}<0.01)$, and the insulin-driven cell growth was downregulated to the level of that without insulin treatment by $5 \mu \mathrm{g} / \mathrm{mL}$ of $\beta$-elemene. (Fig. 3A, B and C). The data suggest that the insulin-driven cell growth is sensitive to $\beta$-elemene treatment in ESFT cells.

To clarify whether the repression on the insulin-driven cell growth by $\beta$-elemene is due to apoptosis, we treated A673 cells with insulin and $\beta$-elemene, and stained the cells with PI/Annexin V. Insulin treatment did not change the ratio of the $\mathrm{PI}^{-} /$Annexin $\mathrm{V}^{+}$cells, whereas $\beta$-elemene (5 and $10 \mu \mathrm{g} / \mathrm{mL}$ ) increased the ratio of the $\mathrm{PI} /$ Annexin $\mathrm{V}^{+}$cells from 2.3 to $4.49 \%$ and $10.96 \%$, respectively (Fig. 3D). The level of cleaved PARP, an apoptosis marker, was decreased by insulin stimulation and also increased remarkably by $\beta$-elemene treatment (Fig. 3E). These data suggest a possibility that $\beta$-elemene induces apoptosis.

We further investigated the anti-proliferative effects of $\beta$-elemene in hepatocellular carcinoma cell HepG2, and $\beta$-elemene treatment also led to significant reduction of the insulin-driven cell growth in a dose-dependent manner $(P<0.01)$ (Fig. $3 \mathrm{~F}$ and $\mathrm{G})$. To examine whether $\beta$-elemene is toxic to normal cells, we selected an insulinresponsible normal cell, a normal hepatocyte cell line THLE2 to study the effects. $\beta$-elemene treatment did not show any proliferation repression in THLE2 cells even at $50 \mu \mathrm{g} / \mathrm{mL}$, which is comparative to the IC50 of $\beta$-elemene in ESFT cells and HepG2 cells. THLE2 cells only showed a $10 \%$ drop in cell viability in response to $100 \mu \mathrm{g} / \mathrm{mL}$ of $\beta$-elemene, whereas A673 cells exhibited an approximate $95 \%$ reduction (Figs 1A, B and $3 \mathrm{H}, \mathrm{I}$ ). Hence, it is in a tumor-specific manner that $\beta$-elemene may inhibit cellular proliferation.

This work is licensed under a Creative Commons Attribution 4.0 International License. 
A

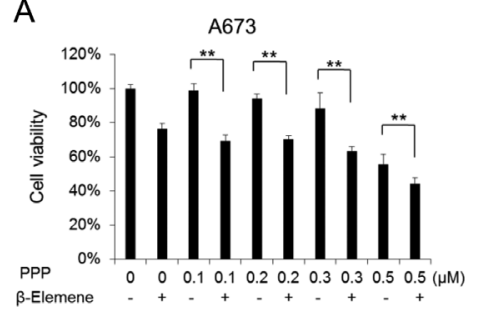

C

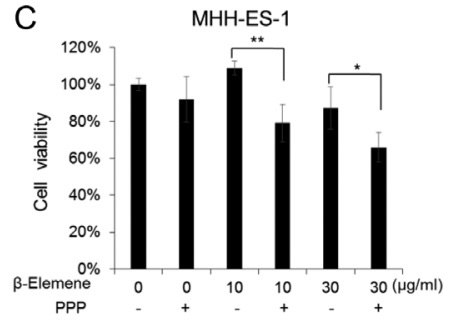

E

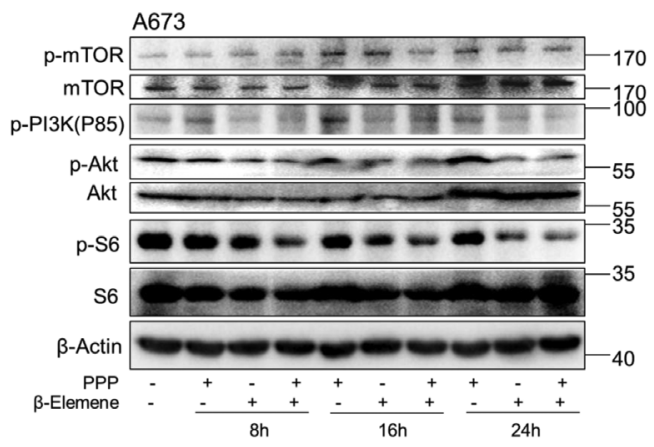

B

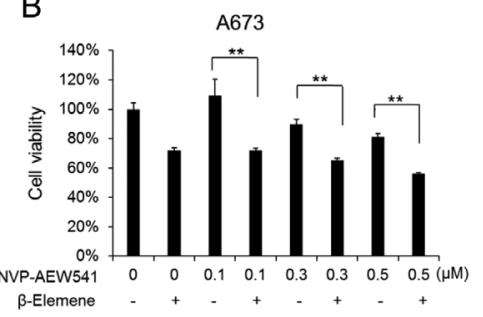

D

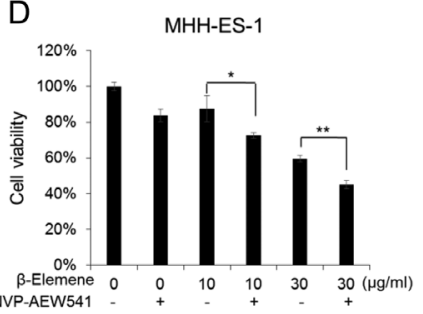

$\mathrm{F}$
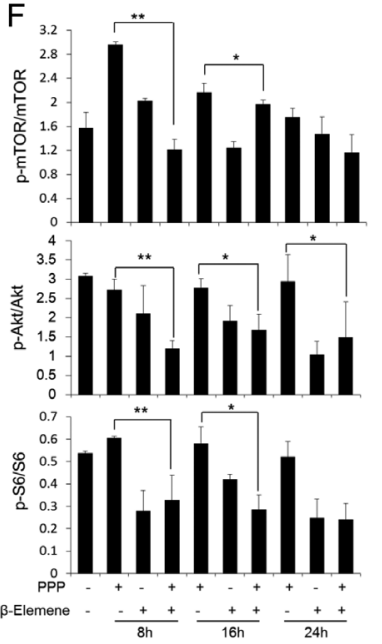

Figure 2

Effects of $\beta$-elemene in combination with IGF1R inhibitors on the proliferation of ESFT cells and the signaling pathway. The cells were treated with IGF1R inhibitors and increasing concentrations of $\beta$-elemene. ( $A, B, C$ and $D)$ Cell viability assays $48 \mathrm{~h}$ after the treatment. PPP, $0.1 \mu \mathrm{M}$ ( $A$ and $C$ ), NVP-AEW541, $0.2 \mu \mathrm{M}$ (B and D). All the experiments were conducted in triplicate, and three independent experiments were performed. $* *, P<0.01 ; *, P<0.05$, indicates the significant difference from the particular treated cells as labeled. Bars, S.D. (E) The cells treated with combination of PPP $(0.2 \mu \mathrm{M})$ and $\beta$-elemene $(30 \mu \mathrm{g} / \mathrm{mL})$ were harvested at the indicated time, and the levels of the indicated proteins were analyzed by Western blot. S6, S6 ribosomal protein. (F) The quantification of the phosphoprotein from three independent experiments. ** $P<0.01$ and $* P<0.05$ indicate the significant difference from the particular treated cells as labeled.

\section{$\beta$-elemene inhibits IR phosphorylation and the downstream signaling specifically in tumor cells}

We next investigated the effects of $\beta$-elemene on the activation of signaling pathways in response to insulin stimulation (Fig. 4). When we treated A673 cells with $\beta$-elemene together with insulin, $\beta$-elemene treatment decreased notably the phosphorylation of S6 ribosomal protein, PI3K and PRAS40 but not ERK1/2 and Akt stimulated by insulin $4 \mathrm{~h}$ after the treatment. The phosphorylation repression by $\beta$-elemene was maintained at least till $24 \mathrm{~h}$ after the treatment (Fig. 4A, $\mathrm{B}, \mathrm{C}$ and $\mathrm{D})$. That the activation of both mTOR and PI3K pathways is inhibited by $\beta$-elemene treatment implicates a possibility of an activation inhibition to a common upstream factor of these two pathways. Consequently, we studied the effects of $\beta$-elemene treatment on IR phosphorylation. The expression plasmid of human IR-B was transfected into A673 cells to construct an IR-hyper-expression model, and the cells were treated with insulin or/and $\beta$-elemene after the starvation. We performed the immunoprecipitation with anti-IR antibody followed by the western blot with anti-p-IR antibody. A remarkable downregulation of IR phosphorylation was verified in $\beta$-elemene-treated cells (Fig. 4D). To investigate the effects of $\beta$-elemene on the phosphorylation of IR-A, we treated the cells with IGF2. The level of phosphorylated IR significantly upregulated by IGF2 was notably downregulated by $\beta$-elemene treatment (Fig. 4E). Another anti-p-IR (Y1361, Abcam) antibody has been recently used to recognize p-IR in several other studies (Ilatovskaya et al. 2015, Kruger et al. 2015, Brenachot et al. 2017), which was selected for the next experiments after confirming its specificity (Fig. 4H). In MHH-ES-1 cells, similar results have been obtained. The activation of mTOR and PI3K, and the phosphorylation of IR in response to insulin stimulation were inhibited by $\beta$-elemene treatment. Meanwhile, the

This work is licensed under a Creative Commons Attribution 4.0 International License. 

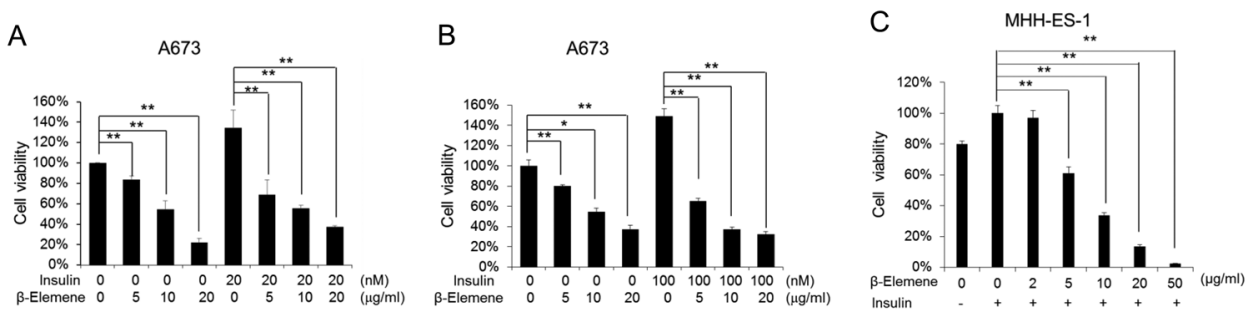

D

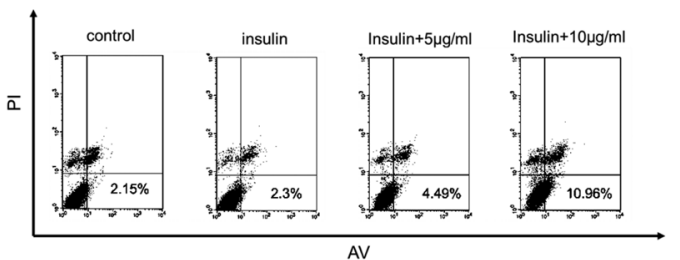

E
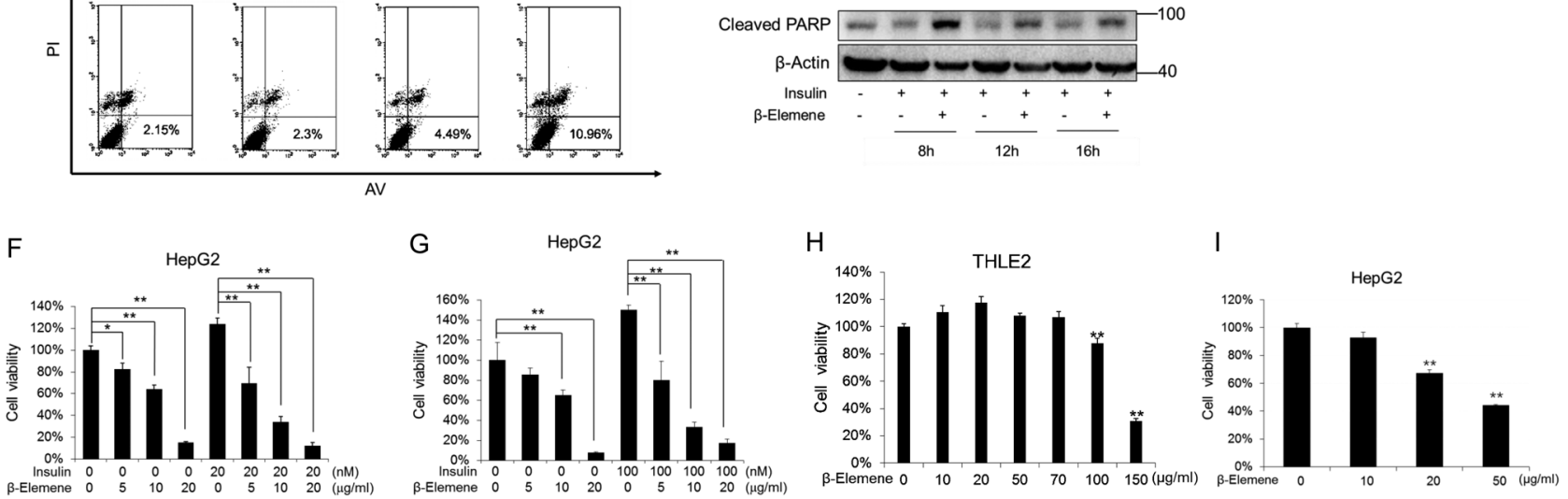

Figure 3

Effects of $\beta$-elemene on the insulin-induced cellular proliferation. The cells were treated with or without (-) $20 \mathrm{nM}(\mathrm{A}$ and F) or $100 \mathrm{nM}(\mathrm{B}, \mathrm{C}, \mathrm{D}, \mathrm{E}$ and G) of insulin and $\beta$-elemene after $24 \mathrm{~h}$ starvation. (A, B and C) Cell viability assays were performed $48 \mathrm{~h}$ after the treatment. (D) Twenty four hours later, the cells were analyzed by flow cytometry after stained by annexin V (AV) and PI. (E) The cells were harvested at the indicated time, and the levels of cleaved PARP were analyzed by Western blot. ( $F$ and G) Cell viability assays were performed $48 \mathrm{~h}$ after the treatment. ( $\mathrm{H}$ and I) Cell viability assays for THLE2 and HepG2 cells. All the experiments were conducted in triplicate, and three independent experiments were performed. $* \star, P<0.01$, indicates the significant difference from the particular treated cells as labeled ( $, B, C, F$ and $G)$ or the untreated cells ( $H$ and I). Bars, s.D.

level of cleaved PARP decreased by insulin stimulation was increased by $\beta$-elemene treatment (Fig. $4 \mathrm{~F}$ and $\mathrm{G}$ ).

We also tested whether $\beta$-elemene could repress the activation of insulin signaling pathway in melanoma cell A2058 and hepatocellular carcinoma cell HepG2. The results showed that the phosphorylation of S6 ribosomal protein, PDK1, PRAS40 and IR was inhibited greatly, and the level of cleaved PARP was increased by $\beta$-elemene treatment (Fig. 5A, B and Supplementary Fig. 1, see section on supplementary data given at the end of this article).

Due to the great repression of $\beta$-elemene on IR phosphorylation and the downstream signaling, it should be very important to verify whether there is an impairment in normal cells. Next, we treated THLE2 cells with insulin or/and $\beta$-elemene after the starvation. Surprisingly, the phosphorylation of IR, S6 ribosomal protein, PI3K, Akt and PRAS40 was not decreased at all in $\beta$-elemene-treated cells compared with the control cells (Fig. 5C). These data suggest that $\beta$-elemene inhibits IR phosphorylation and the downstream signaling in a tumor-specific manner, which may be due to the hyper-expression of IR in tumor cells (Fig. 5D).

\section{$\beta$-elemene inhibits the tumor growth in ESFT xenograft models}

Based on the in vitro results, we further explored the possibility that $\beta$-elemene inhibits the growth of ESFT xenografts in vivo. Treatment of the mice bearing A673 xenografts with $\beta$-elemene at dose levels of 50 or $100 \mathrm{mg} / \mathrm{kg}$ resulted in tumor growth inhibition of 25 or $72 \%$ compared with the control (Fig. 6A and B).

Moreover, immunohistological analyses indicated that anti-p-IR or anti-p-S6 ribosomal protein antibody staining of tumor tissues from mice of the $\beta$-elemene $(100 \mathrm{mg} / \mathrm{kg})$ groups was considerably weaker compared with the control groups (Fig. 6C and D). These data indicate that $\beta$-elemene treatment significantly suppresses the tumor growth of ESFT xenografts in vivo by inhibiting IR phosphorylation and the downstream signaling.

\section{Discussion}

ESFTs are highly malignant tumors, and conventional treatments did not bring approving results. $\beta$-elemene is 
A

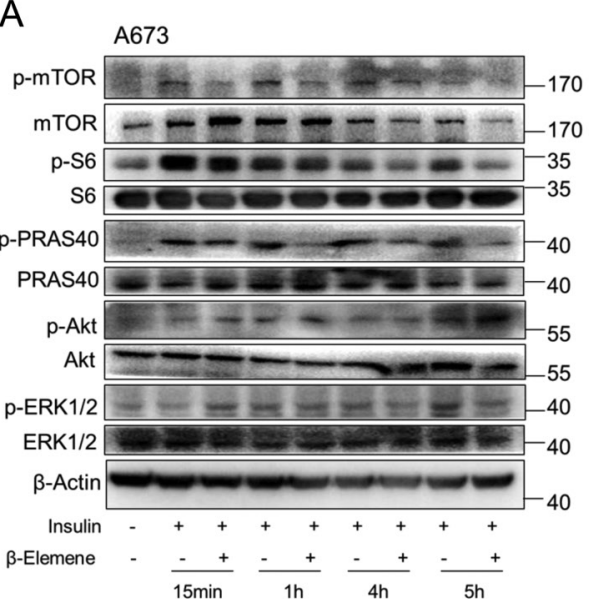

B

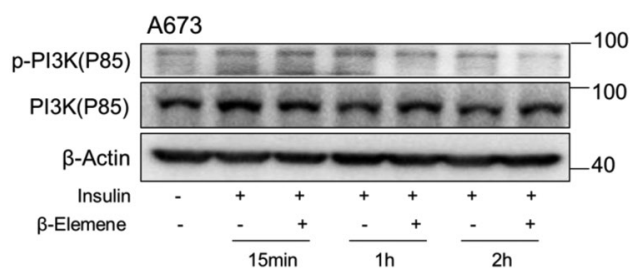

C

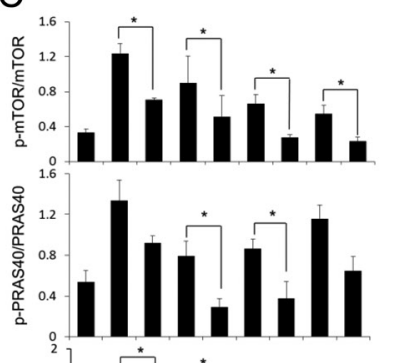

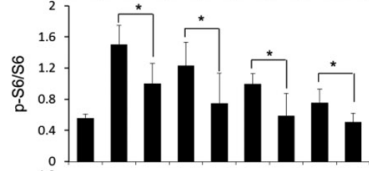

$\left[\begin{array}{cc}0.2 \\ 1.2\end{array}\right]$

IIIIIIII

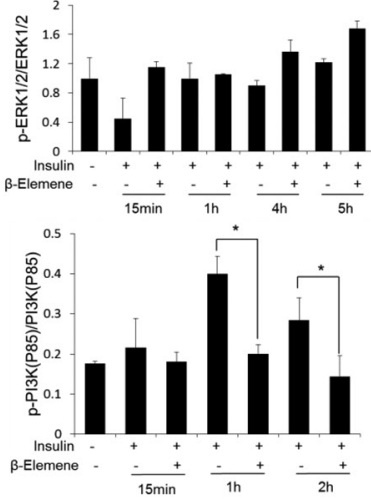

D

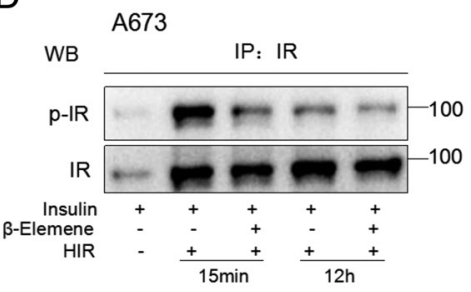

E

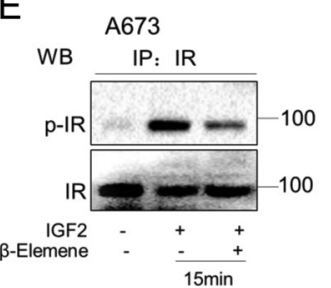

$\mathrm{F}$

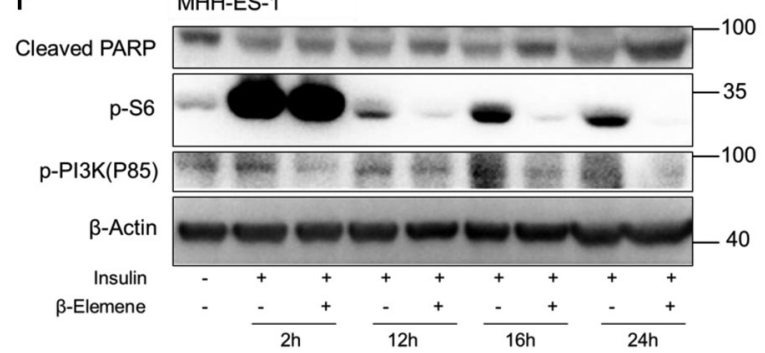

G

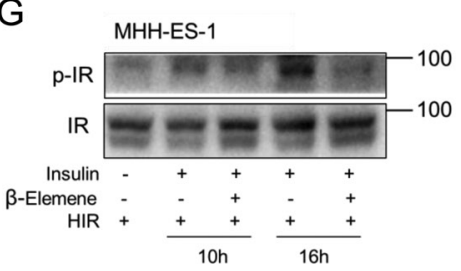

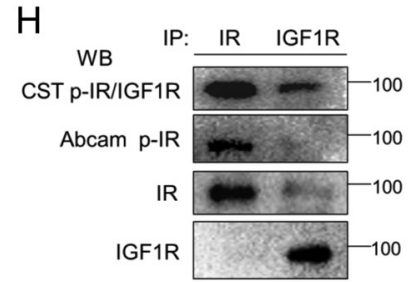

Figure 4

Effects of $\beta$-elemene on the phosphorylation of insulin pathway signaling factors in ESFT cells. A673 cells (A, B, C, D and E) were treated with or without (-) insulin $(100 \mathrm{nM})(\mathrm{A}, \mathrm{B}, \mathrm{C}$ and $\mathrm{D})$, or IGF2 $(100 \mathrm{ng} / \mathrm{mL})(\mathrm{E})$ together with $\beta$-elemene $(10 \mu \mathrm{g} / \mathrm{mL})$ after $24 \mathrm{~h}$ starvation. MHH-ES-1 cells (F and G) were treated with or without (-) insulin $(100 \mathrm{nM})$ and $\beta$-elemene $(10 \mu \mathrm{g} / \mathrm{mL})$ after $24 \mathrm{~h}$ starvation. Human IR (HIR) expression plasmid was introduced into A673 (D) or MHH-ES-1 (G) cells. The cells were harvested at the indicated time, and the levels of the indicated proteins were analyzed by Western blot. (C) The quantification of phospho-protein from three independent experiments. ${ }^{*}, P<0.05$, indicates the significant difference from the particular treated cells as labeled. (H) A673 cells were harvested and applied to immunoprecipitation with anti-IR or anti-IGF1R antibody, followed by the Western blot with p-IGF1R (Y1135/1136)/p-IR (Y1150/1151) (Cell Signaling) or p-IR (Y1361, Abcam) antibody. S6, S6 ribosomal protein.

effective against a wide variety of tumors (Ding et al. 2013, Liu et al. 2014, Zhu et al. 2014, Zhao et al. 2015, Wu et al. 2017), whereas there was no evidence demonstrating the potential of $\beta$-elemene in controlling ESFTs before. We show here that $\beta$-elemene suppresses the proliferation of ESFT cells and xenografts and induces the apoptosis of ESFT cells (Figs 1, 2, 3, 4 and 6).
Recent studies concerning novel treatments of ESFTs focus on targeting therapies and immunotherapies. Among these therapies, IGF1R blockade is considered to be effective toward ESFTs in clinical trials (Kurzrock et al. 2010, Olmos et al. 2010). Unfortunately, many patients develop resistance to the therapy and disease recurrence (Toretsky \& Gorlick 2010). IR-A is reported

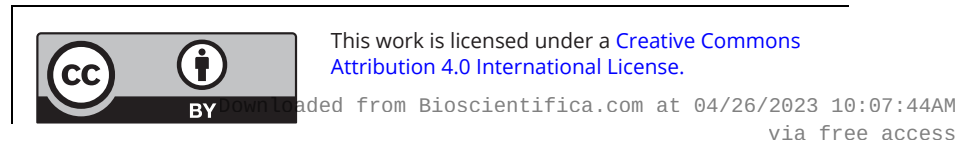



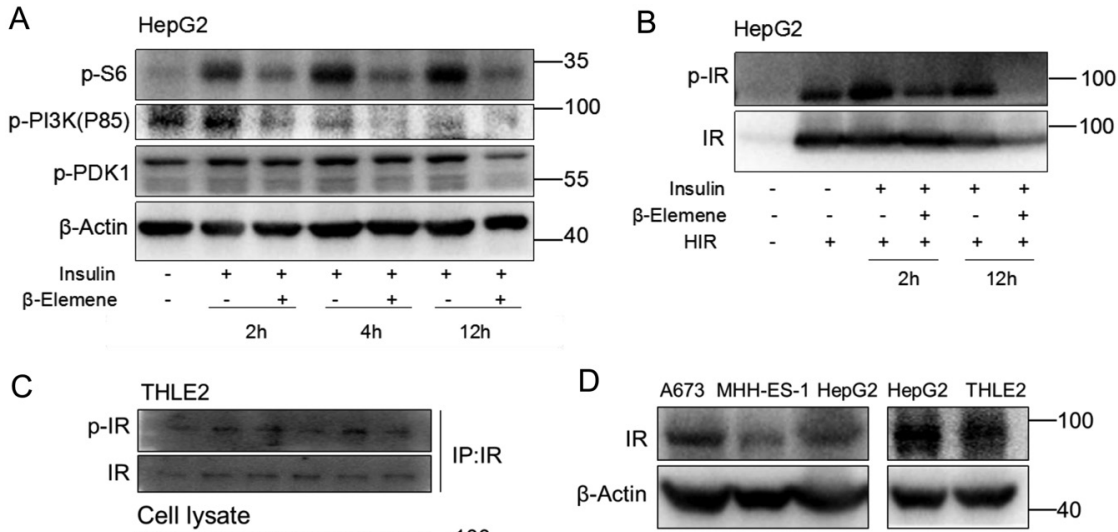

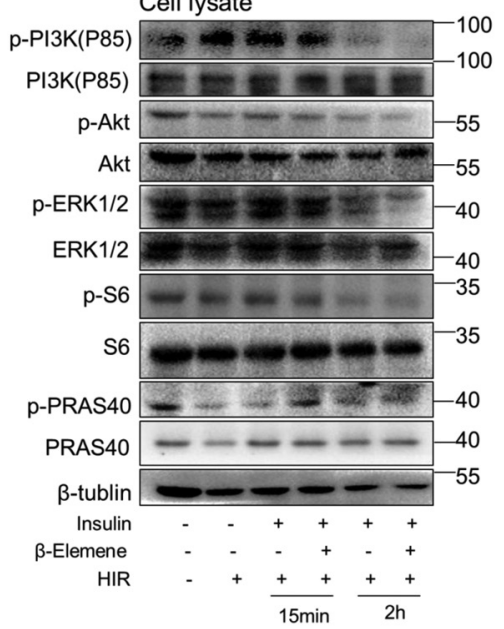

to be expressed more than IR-B isoform in ESFT cells (Garofalo et al. 2011). Since IGF2 is produced by ESFT cells, resistance to IGF1R therapy is believed to be driven by an IGF2/IR-A loop (Zhang et al. 2007, Hendrickson \& Haluska 2009, Garofalo et al. 2011). Therefore, suppression of IR signaling simultaneously combined with IGF1R blockade treatment could be expected. For example, IGF1 blockade becomes more effective to ESFTs in combination with mTOR inhibitors (Zhong et al. 2014) and PI3K inhibitors (Anderson et al. 2015). Our results show that $\beta$-elemene inhibits both IGF1/2- and insulindriven cellular proliferation (Figs $1 \mathrm{~F}, \mathrm{H}$ and $3 \mathrm{~A}, \mathrm{~B}, \mathrm{C}, \mathrm{F}$, $\mathrm{G})$, and $\beta$-elemene represses the activation of both IR-A and IR-B (Fig. 4D and E), the possible causes of IGF1R blockade resistance. In combination of IGF1R inhibitors, $\beta$-elemene enhances the antitumor activities of IGF1R inhibitors in ESFT cells and represses the activation of mTOR and PI3K (Fig. 2). It is anticipated that $\beta$-elemene in combination with IGF1R inhibitors should be effective to IGF1 signaling hyperactivated tumors by targeting both IR phosphorylation and IGF1 signaling.

Several studies have demonstrated the mechanisms involved in the antitumor effects of $\beta$-elemene

\begin{abstract}
Figure 5
Effects of $\beta$-elemene on the phosphorylation of insulin pathway signaling factors in tumor cells and normal hepatocytes. HepG2 (A and B) and THLE2 ( $C$ and $D$ ) cells were treated with or without $(-)$ insulin $(100 \mathrm{nM})$ and $\beta$-elemene $(10 \mu \mathrm{g} / \mathrm{mL})$ after $24 \mathrm{~h}$ starvation. Human IR (HIR) expression plasmid was introduced into HepG2 (B) or THLE2 (C) cells. The cells were harvested at the indicated time, and applied to immunoprecipitation with anti-IR antibody followed by Western blot (C) or directly applied to Western blot (A and B). (D) Western blot for endogenous IR. S6, S6 ribosomal protein.
\end{abstract}

(Li et al. 2013, 2016, Liu et al. 2014, Zhao et al. 2015, $\mathrm{Wu}$ et al. 2017), whereas the detailed molecular mechanism remains to be clarified. We show here that $\beta$-elemene inhibits the phosphorylation of IR and the downstream factors, including PI3K, PRAS40, mTOR and S6 ribosomal protein specifically in tumor cells (Figs 4, 5 and Table 1). Therefore, IR phosphorylation inhibition could be the important mechanism through which $\beta$-elemene suppresses cellular proliferation. Surprisingly, although $\beta$-elemene suppressed notably the phosphorylation of Akt induced by IGF1R blockade, the insulin-stimulated phosphorylation of Akt was not inhibited significantly by $\beta$-elemene (Figs $2 \mathrm{E}$ and $4 \mathrm{~A})$. These data imply that the phosphorylation of Akt might be controlled by other upstream signaling besides IR signaling. In addition, tumor cells were also reported to overcome IGF1R inhibition in an EGFRdependent manner (Desbois-Mouthon et al. 2009), indicating that EGF signaling could be another way mediating IGF1R blockade resistance. To clarify this possibility, we examined the alteration of ERK1/2 phosphorylation. However, ERK1/2 phosphorylation was not upregulated after IGF1R blockade treatment, https://erc.bioscientifica.com https://doi.org/10.1530/ERC-18-0370 (c) 2019 The authors Published by Bioscientifica Ltd. Printed in Great Britain
This work is licensed under a Creative Commons Attribution 4.0 International License. ded from Bioscientifica.com at 04/26/2023 10:07:44AM 
A

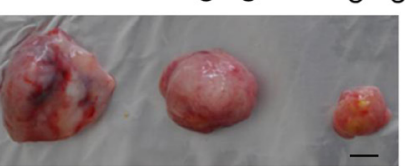

B

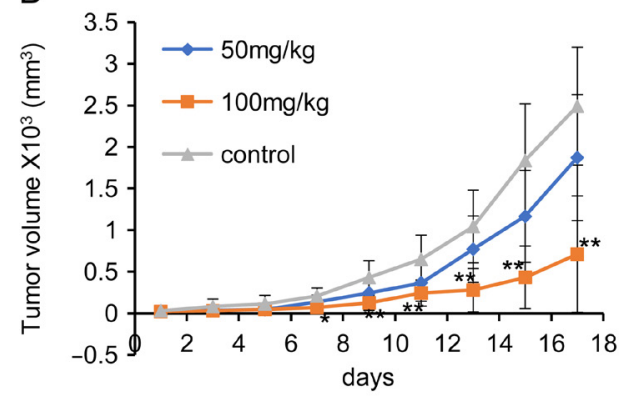

C

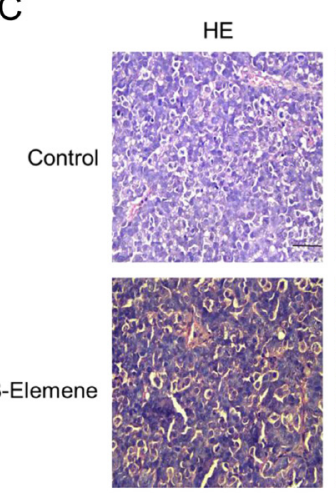

$\mathrm{p}-\mathrm{IR}$

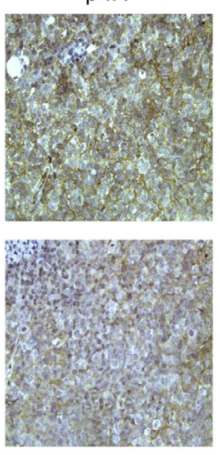

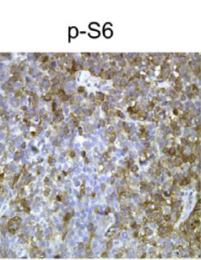

D

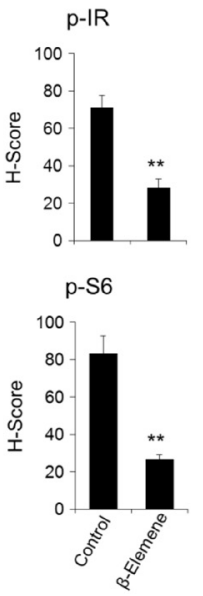

\section{Figure 6}

Effects of $\beta$-elemene on ESFT growth in vivo. The mice bearing $A 673$ xenografts were treated with increasing concentrations of $\beta$-elemene. Eight xenografts were involved for each dose. (A) On day 18 , tumors were dissected and obtained. Representative images are presented. Scale bar, $5 \mathrm{~mm}$. (B) Tumor volumes were recorded every 2 days. ${ }^{*} P<0.01 ; * P<0.05$ indicate the significant difference from the control mice. (C) Immunohistochemical analysis of the $\mathrm{p}$-IR and p-S6 ribosomal protein levels and hematoxylin and eosin staining in tumor samples treated with or without (control) $\beta$-elemene $(100 \mathrm{mg} / \mathrm{kg}$ ). Scale bar, $50 \mu \mathrm{m}$. (D) Quantification of p-IR and p-S6 ribosomal protein from three independent samples. ${ }^{*}, P<0.01$, indicates the significant difference from the control mice. A full colour version of this figure is available at https://doi. org/10.1530/ERC-18-0370. and $\beta$-elemene treatment did not show any suppression on ERK1/2 phosphorylation (Fig. 4A).

IR phosphorylation results in different responses in different types of cells. A major consequence of IR activation in liver is the inhibition of gluconeogenesis and the activation of glycogen storage, whereas in epithelial cells is the stimulation of proliferation and the inhibition of apoptosis (Venkateswaran et al. 2007, Algire et al. 2011). Targeting IR results in the growth repression of tumor cells (Chan et al. 2016). Since the amplification and mutation of IR are rare in tumors (Pollak 2012), and IR signaling plays a crucial role in glucose metabolism, the IR blockade is always considered too dangerous to be used against tumors. In addition, the compensatory hyperinsulinemia caused by PI3K or mTOR inhibitors has been observed due to the signaling inhibition in normal tissues
(Hernandez-Fisac et al. 2007, Chandarlapaty et al. 2011). Surprisingly, besides ESFT cells, $\beta$-elemene could inhibit the insulin-driven proliferation and IR phosphorylation in hepatocellular carcinoma and melanoma cells (Fig. 5B and Supplementary Fig. 1B). However, $\beta$-elemene does not show any repression effects on the growth of normal heptocytes at the toxic concentrations in ESFT cells and hepatocellular carcinoma cells (Figs 1A, B and 3H, I). Further, $\beta$-elemene inhibits neither IR phosphorylation nor the downstream signaling in normal hepatocytes (Fig. 5C and D). Thus, $\beta$-elemene provides a possible way to target IR phosphorylation in tumor cells without changing the IR signaling in normal cells. Patients with type 2 diabetes or obesity have modestly increased cancer risk and/or cancer prognosis (Calle et al. 2003, Ma et al. 2004, 2008, Giovannucci et al. 2010, Algire et al. 2011).

Table 1 The results of the alteration of the protein phosphorylation in different cell lines.

\begin{tabular}{lccc} 
Cell lines & & p-IR & p-PI3Kp85 \\
\cline { 1 - 2 } A673 & $\downarrow$ & $\downarrow$ & $\downarrow$ \\
MHH-ES1 & $\downarrow$ & $\downarrow$ \\
HepG2 & $\downarrow$ & $\downarrow$ \\
A2058 & - & $\downarrow$ \\
THLE2 & & - \\
\hline
\end{tabular}

\begin{tabular}{c}
\hline P-PRAS40 \\
\hline \\
NA \\
NA \\
$\downarrow$ \\
- \\
\hline
\end{tabular}

\begin{tabular}{c} 
p-mTOR \\
$\downarrow$ \\
NA \\
NA \\
NA \\
NA \\
\hline
\end{tabular}

\begin{tabular}{c}
\hline p-S6 \\
\hline$\downarrow$ \\
$\downarrow$ \\
$\downarrow$ \\
$\downarrow$ \\
- \\
\hline
\end{tabular}

\begin{tabular}{c}
\hline p-Akt \\
\hline- \\
NA \\
NA \\
NA \\
- \\
\hline
\end{tabular}

\begin{tabular}{c}
\hline P-ERK \\
\hline- \\
NA \\
NA \\
NA \\
-
\end{tabular}

$\downarrow$, decreased; -, not changed; NA, not done.

https://erc.bioscientifica.com https://doi.org/10.1530/ERC-18-0370
(C) 2019 The authors Published by Bioscientifica Ltd. Printed in Great Britain
This work is licensed under a Creative Commons Attribution 4.0 International License. 
This may be at least partly attributable to the exposure to hyperinsulinaemia. Therefore, targeting IR or its downstream signaling could be considered to treat this kind of patients. It may be possible to use $\beta$-elemene to target IR phosphorylation in cancer patients with diabetes or obesity because of the low adverse effects of $\beta$-elemene on IR signaling in normal cells.

However, the mechanism of $\beta$-elemene targeting IR phosphorylation in detail remains largely unknown. Since these effects of $\beta$-elemene are tumor specific, and the amplification and mutation of IR are rare in tumors, we do not consider for a direct phosphorylation repression of IR by $\beta$-elemene. The deficiency of various phosphatases in tumor has been reported (Kleppe et al. 2010, Shields et al. 2013, Le Sommer et al. 2018); thus, we hypothesize that $\beta$-elemene might induce the expression of IR-associated phosphatases in tumor cells, resulting in the suppression of IR phosphorylation. More studies are needed to clarify this issue. Taken together, our results show that $\beta$-elemene targets IR phosphorylation and the downstream signaling to inhibit ESFT growth and enhance the effects of IGF1R inhibitors on ESFT cells. This study highlights the potential for optimizing therapeutic strategies of ESFTs by $\beta$-elemene and provides evidence for novel approaches by $\beta$-elemene alone or in combination with IGF1R blockade in ESFTs and IR signaling hyperactivated tumors.

\section{Supplementary data}

This is linked to the online version of the paper at https://doi.org/10.1530/ ERC-18-0370.

\section{Declaration of interest}

The authors declare that there is no conflict of interest that could be perceived as prejudicing the impartiality of the research reported.

\section{Funding}

This work was supported by the Climbing Scholars Supporting Program of Liaoning Province, Natural Science Foundation of Liaoning Province (2014023039), National Natural Science Foundation of China (81772971) and Liaoning Provincial program for Top Discipline of Basic Medical Sciences.

\section{Author contribution statement}

D W, D L and L H designed research; D W, D L, T Z, L G, F M, C Z and L H performed the experiments and analyzed the data; $G \mathrm{~L}$ analyzed the data; $\mathrm{L} \mathrm{H}$ wrote the manuscript. All authors read and approved the manuscript.

\section{Acknowledgements}

The authors thank Dr Pixu Liu of Dalian Medical University for the grateful suggestions.

\section{References}

Algire C, Amrein L, Bazile M, David S, Zakikhani M \& Pollak M 2011 Diet and tumor LKB1 expression interact to determine sensitivity to anti-neoplastic effects of metformin in vivo. Oncogene 30 1174-1182. (https://doi.org/10.1038/onc.2010.483)

Anderson JL, Park A, Akiyama R, Tap WD, Denny CT \& Federman N 2015 Evaluation of in vitro activity of the class I PI3K inhibitor buparlisib (BKM120) in pediatric bone and soft tissue sarcomas. PLOS ONE 10 e0133610. (https://doi.org/10.1371/journal. pone.0133610)

Bollag G, Hirth P, Tsai J, Zhang J, Ibrahim PN, Cho H, Spevak W, Zhang C, Zhang Y, Habets G, et al. 2010 Clinical efficacy of a RAF inhibitor needs broad target blockade in BRAF-mutant melanoma. Nature 467 596-599. (https://doi.org/10.1038/nature09454)

Brenachot X, Ramadori G, Ioris RM, Veyrat-Durebex C, Altirriba J, Aras E, Ljubicic S, Kohno D, Fabbiano S, Clement S, et al. 2017 Hepatic protein tyrosine phosphatase receptor gamma links obesityinduced inflammation to insulin resistance. Nature Communications $\mathbf{8}$ 1820. (https://doi.org/10.1038/s41467-017-02074-2)

Calle EE, Rodriguez C, Walker-Thurmond K \& Thun MJ 2003 Overweight, obesity, and mortality from cancer in a prospectively studied cohort of U.S. adults. New England Journal of Medicine $\mathbf{3 4 8}$ 1625-1638. (https://doi.org/10.1056/NEJMoa021423)

Chan JY, LaPara K \& Yee D 2016 Disruption of insulin receptor function inhibits proliferation in endocrine-resistant breast cancer cells. Oncogene 35 4235-4243. (https://doi.org/10.1038/onc.2015.488)

Chandarlapaty S, Sawai A, Scaltriti M, Rodrik-Outmezguine V, GrbovicHuezo O, Serra V, Majumder PK, Baselga J \& Rosen N 2011 AKT inhibition relieves feedback suppression of receptor tyrosine kinase expression and activity. Cancer Cell 19 58-71. (https://doi. org/10.1016/j.ccr.2010.10.031)

Chitnis MM, Yuen JS, Protheroe AS, Pollak M \& Macaulay VM 2008 The type 1 insulin-like growth factor receptor pathway. Clinical Cancer Research 14 6364-6370. (https://doi.org/10.1158/1078-0432.CCR-074879)

Desbois-Mouthon C, Baron A, Blivet-Van Eggelpoel MJ, Fartoux L, Venot C, Bladt F, Housset C \& Rosmorduc O 2009 Insulin-like growth factor-1 receptor inhibition induces a resistance mechanism via the epidermal growth factor receptor/HER3/AKT signaling pathway: rational basis for cotargeting insulin-like growth factor-1 receptor and epidermal growth factor receptor in hepatocellular carcinoma. Clinical Cancer Research 15 5445-5456. (https://doi. org/10.1158/1078-0432.CCR-08-2980)

Ding XF, Shen M, Xu LY, Dong JH \& Chen G 2013 13,14-bis(cis-3,5dimethyl-1-piperazinyl)-beta-elemene, a novel beta-elemene derivative, shows potent antitumor activities via inhibition of mTOR in human breast cancer cells. Oncology Letters 5 1554-1558. (https:// doi.org/10.3892/ol.2013.1213)

France KA, Anderson JL, Park A \& Denny CT 2011 Oncogenic fusion protein EWS/FLI1 down-regulates gene expression by both transcriptional and posttranscriptional mechanisms. Journal of Biological Chemistry 286 22750-22757. (https://doi.org/10.1074/jbc. M111.225433)

Garcia-Echeverria C, Pearson MA, Marti A, Meyer T, Mestan J, Zimmermann J, Gao J, Brueggen J, Capraro HG, Cozens R, et al. 2004 In vivo antitumor activity of NVP-AEW541-A novel, potent, and selective inhibitor of the IGF-IR kinase. Cancer Cell 5 231-239. (https://doi.org/10.1016/S1535-6108(04)00051-0)

Garofalo C, Manara MC, Nicoletti G, Marino MT, Lollini PL, Astolfi A, Pandini G, Lopez-Guerrero JA, Schaefer KL, Belfiore A, et al. 2011 Efficacy of and resistance to anti-IGF-1R therapies in Ewing's sarcoma is dependent on insulin receptor signaling. Oncogene $\mathbf{3 0}$ 2730-2740. (https://doi.org/10.1038/onc.2010.640)

Giovannucci E, Harlan DM, Archer MC, Bergenstal RM, Gapstur SM, Habel LA, Pollak M, Regensteiner JG \& Yee D 2010 Diabetes and

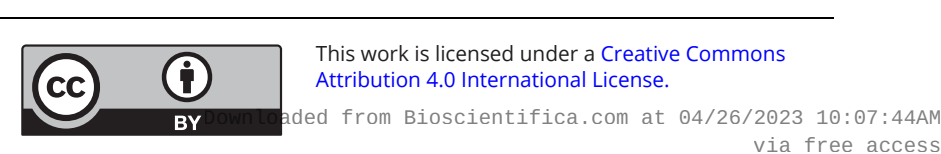


cancer: a consensus report. CA: A Cancer Journal for Clinicians 60 207-221. (https://doi.org/10.3322/caac.20078)

Girnita A, Girnita L, del Prete F, Bartolazzi A, Larsson O \& Axelson M 2004 Cyclolignans as inhibitors of the insulin-like growth factor-1 receptor and malignant cell growth. Cancer Research 64 236-242. (https://doi.org/10.1158/0008-5472.CAN-03-2522)

Gualberto A \& Pollak M 2009 Emerging role of insulin-like growth factor receptor inhibitors in oncology: early clinical trial results and future directions. Oncogene 28 3009-3021. (https://doi.org/10.1038/ onc.2009.172)

Hendrickson AW \& Haluska P 2009 Resistance pathways relevant to insulin-like growth factor-1 receptor-targeted therapy. Current Opinion in Investigational Drugs 10 1032-1040.

Hernandez-Fisac I, Pizarro-Delgado J, Calle C, Marques M, Sanchez A, Barrientos A \& Tamarit-Rodriguez J 2007 Tacrolimus-induced diabetes in rats courses with suppressed insulin gene expression in pancreatic islets. American Journal of Transplantation 7 2455-2462. (https://doi.org/10.1111/j.1600-6143.2007.01946.x)

Huang L, Kuwahara I \& Matsumoto K 2014 EWS represses cofilin 1 expression by inducing nuclear retention of cofilin 1 mRNA. Oncogene 33 2995-3003. (https://doi.org/10.1038/onc.2013.255)

Ilatovskaya DV, Levchenko V, Brands MW, Pavlov TS \& Staruschenko A 2015 Cross-talk between insulin and IGF-1 receptors in the cortical collecting duct principal cells: implication for ENaC-mediated $\mathrm{Na}+$ reabsorption. American Journal of Physiology-Renal Physiology $\mathbf{3 0 8}$ F713-F719. (https://doi.org/10.1152/ajprenal.00081.2014)

Jacob KK, Whittaker J \& Stanley FM 2002 Insulin receptor tyrosine kinase activity and phosphorylation of tyrosines 1162 and 1163 are required for insulin-increased prolactin gene expression. Molecular and Cellular Endocrinology 186 7-16. (https://doi.org/10.1016/S03037207(01)00674-8)

Kleppe M, Lahortiga I, El Chaar T, De Keersmaecker K, Mentens N, Graux C, Van Roosbroeck K, Ferrando AA, Langerak AW, Meijerink JP, et al. 2010 Deletion of the protein tyrosine phosphatase gene PTPN2 in T-cell acute lymphoblastic leukemia. Nature Genetics 42 530-535. (https://doi.org/10.1038/ng.587)

Kruger J, Brachs S, Trappiel M, Kintscher U, Meyborg H, Wellnhofer E, Thone-Reineke C, Stawowy P, Ostman A, Birkenfeld AL, et al. 2015 Enhanced insulin signaling in density-enhanced phosphatase-1 (DEP-1) knockout mice. Molecular Metabolism 4 325-336. (https:// doi.org/10.1016/j.molmet.2015.02.001)

Kurzrock R, Patnaik A, Aisner J, Warren T, Leong S, Benjamin R, Eckhardt SG, Eid JE, Greig G, Habben K, et al. 2010 A phase I study of weekly R1507, a human monoclonal antibody insulin-like growth factor-I receptor antagonist, in patients with advanced solid tumors. Clinical Cancer Research 16 2458-2465. (https://doi. org/10.1158/1078-0432.CCR-09-3220)

Lamhamedi-Cherradi SE, Menegaz BA, Ramamoorthy V, Vishwamitra D, Wang Y, Maywald RL, Buford AS, Fokt I, Skora S, Wang J, et al. 2016 IGF-1R and mTOR blockade: novel resistance mechanisms and synergistic drug combinations for Ewing sarcoma. Journal of the National Cancer Institute 108 djw182. (https://doi.org/10.1093/jnci/ djw182)

Le Sommer S, Morrice N, Pesaresi M, Thompson D, Vickers MA, Murray GI, Mody N, Neel BG, Bence KK, Wilson HM, et al. 2018 Deficiency in protein tyrosine phosphatase PTP1B shortens lifespan and leads to development of acute leukemia. Cancer Research $\mathbf{7 8}$ 75-87. (https://doi.org/10.1158/0008-5472.CAN-17-0946)

Li QQ, Lee RX, Liang H, Wang G, Li JM, Zhong Y \& Reed E 2013 betaElemene enhances susceptibility to cisplatin in resistant ovarian carcinoma cells via downregulation of ERCC-1 and XIAP and inactivation of JNK. International Journal of Oncology 43 721-728. (https://doi.org/10.3892/ijo.2013.1996)

Li X, Lin Z, Zhang B, Guo L, Liu S, Li H, Zhang J \& Ye Q 2016 betaelemene sensitizes hepatocellular carcinoma cells to oxaliplatin by preventing oxaliplatin-induced degradation of copper transporter 1 . Scientific Reports 6 21010. (https://doi.org/10.1038/srep21010)

Liu JS, He SC, Zhang ZL, Chen R, Fan L, Qiu GL, Chang S, Li L \& Che XM 2014 Anticancer effects of beta-elemene in gastric cancer cells and its potential underlying proteins: a proteomic study. Oncology Reports 32 2635-2647. (https://doi.org/10.3892/ or.2014.3490)

Ma J, Giovannucci E, Pollak M, Leavitt A, Tao Y, Gaziano JM \& Stampfer MJ 2004 A prospective study of plasma C-peptide and colorectal cancer risk in men. Journal of the National Cancer Institute 96 546-553. (https://doi.org/10.1093/jnci/djh082)

Ma J, Li H, Giovannucci E, Mucci L, Qiu W, Nguyen PL, Gaziano JM, Pollak M \& Stampfer MJ 2008 Prediagnostic body-mass index, plasma C-peptide concentration, and prostate cancer-specific mortality in men with prostate cancer: a long-term survival analysis. Lancet Oncology 9 1039-1047. (https://doi.org/10.1016/S14702045(08)70235-3)

Olmos D, Postel-Vinay S, Molife LR, Okuno SH, Schuetze SM, Paccagnella ML, Batzel GN, Yin D, Pritchard-Jones K, Judson I, et al. 2010 Safety, pharmacokinetics, and preliminary activity of the antiIGF-1R antibody figitumumab (CP-751,871) in patients with sarcoma and Ewing's sarcoma: a phase 1 expansion cohort study. Lancet Oncology 11 129-135. (https://doi.org/10.1016/S1470-2045(09)70354-7)

Pollak M 2012 The insulin and insulin-like growth factor receptor family in neoplasia: an update. Nature Reviews Cancer 12 159-169. (https:// doi.org/10.1038/nrc3215)

Prieur A, Tirode F, Cohen P \& Delattre O 2004 EWS/FLI-1 silencing and gene profiling of Ewing cells reveal downstream oncogenic pathways and a crucial role for repression of insulin-like growth factor binding protein 3. Molecular and Cellular Biology 24 7275-7283. (https://doi. org/10.1128/MCB.24.16.7275-7283.2004)

Renehan AG, Zwahlen M, Minder C, O’Dwyer ST, Shalet SM \& Egger M 2004 Insulin-like growth factor (IGF)-I, IGF binding protein-3, and cancer risk: systematic review and meta-regression analysis. Lancet 363 1346-1353. (https://doi.org/10.1016/S0140-6736(04)16044-3)

Ryan PD \& Goss PE 2008 The emerging role of the insulin-like growth factor pathway as a therapeutic target in cancer. Oncologist 13 16-24. (https://doi.org/10.1634/theoncologist.2007-0199)

Sachdev D \& Yee D 2007 Disrupting insulin-like growth factor signaling as a potential cancer therapy. Molecular Cancer Therapeutics 6 1-12. (https://doi.org/10.1158/1535-7163.MCT-06-0080)

Sciacca L, Mineo R, Pandini G, Murabito A, Vigneri R \& Belfiore A 2002 In IGF-I receptor-deficient leiomyosarcoma cells autocrine IGF-II induces cell invasion and protection from apoptosis via the insulin receptor isoform A. Oncogene 21 8240-8250. (https://doi. org/10.1038/sj.onc.1206058)

Sciacca L, Prisco M, Wu A, Belfiore A, Vigneri R \& Baserga R 2003 Signaling differences from the A and B isoforms of the insulin receptor (IR) in $32 \mathrm{D}$ cells in the presence or absence of IR substrate-1. Endocrinology 144 2650-2658. (https://doi.org/10.1210/ en.2002-0136)

Shields BJ, Wiede F, Gurzov EN, Wee K, Hauser C, Zhu HJ, Molloy TJ, O'Toole SA, Daly RJ, Sutherland RL, et al. 2013 TCPTP regulates SFK and STAT3 signaling and is lost in triple-negative breast cancers. Molecular and Cellular Biology 33 557-570. (https://doi.org/10.1128/ MCB.01016-12)

Tao Y, Pinzi V, Bourhis J \& Deutsch E 2007 Mechanisms of disease: signaling of the insulin-like growth factor 1 receptor pathway therapeutic perspectives in cancer. Nature Clinical Practice Oncology 4 591-602. (https://doi.org/10.1038/ncponc0934)

Toretsky JA \& Gorlick R 2010 IGF-1R targeted treatment of sarcoma. Lancet Oncology 11 105-106. (https://doi.org/10.1016/S14702045(09)70391-2)

Ulanet DB, Ludwig DL, Kahn CR \& Hanahan D 2010 Insulin receptor functionally enhances multistage tumor progression and conveys
This work is licensed under a Creative Commons Attribution 4.0 International License. 
intrinsic resistance to IGF-1R targeted therapy. PNAS $\mathbf{1 0 7}$ 10791-10798. (https://doi.org/10.1073/pnas.0914076107)

Venkateswaran V, Haddad AQ, Fleshner NE, Fan R, Sugar LM, Nam R, Klotz LH \& Pollak M 2007 Association of diet-induced hyperinsulinemia with accelerated growth of prostate cancer (LNCaP) xenografts. Journal of the National Cancer Institute 99 1793-1800. (https://doi.org/10.1093/jnci/djm231)

Wu J, Tang Q, Yang L, Chen Y, Zheng F \& Hann SS 2017 Interplay of DNA methyltransferase 1 and EZH2 through inactivation of Stat3 contributes to beta-elemene-inhibited growth of nasopharyngeal carcinoma cells. Scientific Reports 7 509. (https://doi.org/10.1038/ s41598-017-00626-6)

Zhang H, Pelzer AM, Kiang DT \& Yee D 2007 Down-regulation of type I insulin-like growth factor receptor increases sensitivity of breast cancer cells to insulin. Cancer Research 67 391-397. (https://doi. org/10.1158/0008-5472.CAN-06-1712)
Zhao S, Wu J, Zheng F, Tang Q, Yang L, Li L, Wu W \& Hann SS 2015 beta-elemene inhibited expression of DNA methyltransferase 1 through activation of ERK1/2 and AMPKalpha signalling pathways in human lung cancer cells: the role of Sp1. Journal of Cellular and Molecular Medicine 19 630-641. (https://doi.org/10.1111/ jcmm.12476)

Zhong H, Fazenbaker C, Breen S, Chen C, Huang J, Morehouse C, Yao Y \& Hollingsworth RE 2014 MEDI-573, alone or in combination with mammalian target of rapamycin inhibitors, targets the insulin-like growth factor pathway in sarcomas. Molecular Cancer Therapeutics 13 2662-2673. (https://doi.org/10.1158/1535-7163.MCT-14-0144)

Zhu TZ, Li XM, Luo LH, Song ZQ, Gao X, Li ZQ, Su JY \& Liang GB 2014 beta-elemene inhibits stemness, promotes differentiation and impairs chemoresistance to temozolomide in glioblastoma stem-like cells. International Journal of Oncology 45 699-709. (https://doi. org/10.3892/ijo.2014.2448)

Received in final form 5 November 2018

Accepted 12 November 2018

Accepted Preprint published online 13 November 2018
This work is licensed under a Creative Commons Attribution 4.0 International License. 